\title{
Moisture Dependent Physical and Engineering Properties of Sorghum Grains
}

\author{
S. S. Sabar ${ }^{1}$, S. K. Swain ${ }^{1 *}$, D. Behera ${ }^{1}$, K. Rayaguru ${ }^{2}$, A. K Mohapatra ${ }^{1}$ and A. K. Dash ${ }^{1}$ \\ ${ }^{1}$ Department of Farm Machinery and Power Engineering, ${ }^{2}$ Department of Agricultural \\ Processing and Food Engineering, College of Agricultural Engineering and Technology, \\ OUAT, Bhubaneswar, Odisha-751003, India \\ *Corresponding author
}

A B S T R A C T

\section{Ke y w o r d s \\ Sorghum, \\ Engineering properties, Terminal velocity, Aspect ratio, Coefficient of friction}

\section{Article Info}

Accepted:

20 July 2020

Available Online:

10 August 2020
An experimental study on engineering, frictional, and aerodynamic properties of sorghum grain was conducted which are essential to design different post-harvest gadgets such as threshers, winnowers, and storage bins. Since most of the post-harvest operations of sorghum are accomplished within moisture content range from around $10.0 \%$ to $25.0 \%$ (wb) in India, the study was conducted within the moisture content range from $8.7 \%$ to $21.8 \%$ (wb).It was observed that the linear dimensions such as length, width, and thickness increased with an increase in moisture content in the said range. With an increase in moisture content, the geometrical mean diameter, arithmetic mean diameter, square mean diameter, and equivalent mean diameter increased from 3.20 to $3.53 \mathrm{~mm}, 3.38$ to $3.70 \mathrm{~mm}$, 5.74 to $6.30 \mathrm{~mm}$ and 4.11 to $4.51 \mathrm{~mm}$, respectively. The coefficient friction for glass, mild steel surface, GI sheet, and plywood increased linearly from 0.25 to $0.31,0.26$ to 0.43 , 0.27 to 0.42 , and 0.30 to 0.45 , respectively with an increase in moisture content. It was observed that glass has the lowest coefficient friction whereas plywood has the highest coefficient of friction as compared to other 3 surfaces. Angle of repose, terminal velocity, aspect ratio, sphericity, surface area, volume, and 1000 grain weight were increased from $39.84^{0}$ to $43.19^{0}, 7.06$ to $7.99 \mathrm{~m}^{-\mathrm{s}}, 0.705$ to $0.735 \%, 32.27$ to $39.25 \mathrm{~mm}^{2}, 17.25$ to 23.13 $\mathrm{mm}^{3}$ and 20.67 to $22.01 \mathrm{~g}$, whereas bulk density, true density and porosity decreased from 755.75 to $723.50 \mathrm{~kg} \mathrm{~m}^{-3}, 1671.50$ to $1161.00 \mathrm{~kg} \mathrm{~m}^{-3}$ and 0.53 to $0.37 \%$ within the said moisture content range.

\section{Introduction}

Millet crops or Nutri-Cereals are commonly known as poor man's crop; of late are termed as rich man's diet since they contain a lot of nutrients and vitamins and can tolerate adverse environmental conditions i.e. tolerance to moisture stress, resistant to waterlogging and grown in various soil conditions (Taylor, 2006). Sorghum is cultivated globally in $42 \mathrm{~m}$ ha in 98 countries while it is the fifth most important cereal crop and is the dietary staple of more than 500 million people in more than 30 countries (1, Anonymous). In India, the annual production of sorghum is $4.5 \mathrm{~m}$ MT being cultivated in 
around 9.2 $\mathrm{m}$ ha (2, Anonymous, 1999). Sorghum is one of the important nutri-cereals generally grown by the small and marginal farmers in many states of the country such as Odisha, Maharashtra, Karnataka, Gujarat, Rajasthan, Madhya Pradesh, Andhra Pradesh and Tamil Nadu, etc. Mechanization of different post-harvest operations like threshing, cleaning, grading, etc. of sorghum can reduce the cost of operation, labor requirement and thus increase the net benefit of the small and marginal farmers. It is quite imperative to have a scientific study of the physical and engineering properties of sorghum at different moisture contents for design and development of suitable gadgets for these operations (Gely et al., 2017, Kachru et al., 1994, Sologubik et al., 2013, Kenghe et al., 2015). The physical and aerodynamic properties of sorghum grain in terms of size, shape, weight, diameter, surface area, and bulk density are essentially required for designing the threshing cylinder, threshing element, concave clearance of a thresher, hopper, sieves, etc., concerning size, and slope (Asoegwu et al., 2006, Hurburgh, 1995, Simonyan, 2005, Vilche et al., 2003, Tettamanti et al., 2015). The various machine parameters such as threshing cylinder length, cylinder speed, sieve size, velocity and quantity of airflow, angle of inclination of sieve, etc are designed for the physical properties namely, equivalent diameter, sphericity and aerodynamic properties like terminal velocity and frictional properties such as the angle of repose, and angle of internal friction, etc, (Brooker et al., 1992, Singh et al., , 2004 and Wilhelm et al., 2004, Chang, 1988; Nelson and You, 1989; Nelson, 1980; Mohsenin, 1980, Obi et al., 2014 and Vaughan et al., 1980). A study on the physical properties of Nigerian varieties of sorghum and their behaviour with the moisture content was conducted by Oke (1984) and Mwithiga and Sifuna (2004) where it was reported that the biological nature of the material influences its properties; therefore, the evaluated properties are not universal but rather represent the behaviour of the material under the studied conditions. The present experiment was conducted to study the effect of moisture content on the physical and engineering properties of one popular variety of sorghum grain, grown in the state of Odisha by the majority of small and marginal farmers.

\section{Materials and Methods}

The sorghum grains of one popular variety, namely Pusachari were collected in adequate quantity were collected from the Centre for Pulse Research (OUAT), Ratanpur, Ganjam, Odisha, India. The grain samples were prepared by thorough cleaning to remove foreign materials such as dirt, stones, dust, immature grain, broken grains, and chaffs and sorting them subsequently. The initial moisture contents of these samples were found out following the standard hot-air oven method (AACC, 1995). Since sorghum is harvested at around 25 percent moisture content and stored at around 10 percent in India, the moisture content range for the study of the properties of sorghum grain was decided accordingly (3, Anonymous). To study the effects of moisture content on different physical and engineering properties of sorghum grains, the samples with five levels of moisture contents within the range from 8.7 to 21.8 percent were prepared by adding the desired amount of distilled water as followed by Coşkun et al., (2005), Jambamma, I. K. et al., (2011).The average moisture content of three replications of the prepared samples was recorded and reported as moisture content of the sample. The design of the experiment for the study of different physical properties was Randomized Block Design (RBD) with five treatments (levels of moisture contents) and four replications (values of properties). Statistical analysis of 
the results was conducted in One-factor Analysis using OPSTAT, a free Online Agriculture Data Analysis Tool created by O.P. Sheoran, Computer Programmer at CCS HAU, Hisar, India (4).

\section{Linear dimensions}

Linear dimensions of the sorghum grains, selected randomly from the samples (Var: Pusachariand five levels of moisture contents) were determined by measuring the dimensions along the three principal axes, namely, major (L), medium (W) and minor (T) using an electron microscope with an accuracy of $\pm 0.01 \mathrm{~mm}$ (Mohsenin, 1970, Shashikumar et al., 2018).

\section{Grain size (Dm)}

The average diameter of the grain was calculated by using arithmetic mean and the geometric mean of the three axial dimensions. The arithmetic mean diameter (AMD), geometric mean diameter $(G M D)$, square mean diameter (SMD), and equivalent diameter (EQD) of the grains were calculated by using the following relationships (Mohsenin, 1986).

$$
\begin{aligned}
& \mathrm{AMD}=(L+B+T) / 3 \\
& \mathrm{GMD}=(L B T)^{1 / 3} \\
& \mathrm{SMD}=\sqrt{ }(L B+B T+T L) \\
& \mathrm{EQD}=(A M D+G M D+S M D) / 3
\end{aligned}
$$

\section{Surface area}

Surface area (S) was calculated by using the expression given by (Singh et al., 2010).

$S=\pi *(\mathrm{GMD})^{2}$

Aspect ratio (Ra) is the ratio of longer diameter to shorter diameter, was calculated by using the relationship given by Maduako and Faborode (1990):

$$
\mathrm{Ra}=\frac{\mathrm{B}}{\mathrm{L}} \times 100
$$

\section{Sphericity (Ф)}

Sphericity $(\boldsymbol{\Phi})$ is defined as the ratio of the surface area of the sphere having the same volume as that of the grain to the surface area of the grain and was determined using the following formula (Mohsenin, 1986, Abalone et al., 2004).

$\Phi=\left\{(\mathrm{LBT})^{1 / 3}\right\} / L \quad \ldots$

where,

$\mathrm{L}=$ length of grain, $\mathrm{mm}$

$\mathrm{B}=$ width of grain, $\mathrm{mm}$

$\mathrm{T}=$ thickness of grain, $\mathrm{mm}$

\section{Volume (V)}

The volume of the grain was determined by taking the dimensions of the two varieties of the grains in three axes of length, width, and thickness in 10 replications, and then the volume was estimated using the relationship as described by Mohsenin (1986).

\section{Angle of Repose ( $\theta)$}

The angle of repose is the angle with the horizontal at which the material will stand when piled. This was determined by using the apparatus consisting of a plywood box of 140 x $160 \times 35 \mathrm{~mm}$ and plates fixed and adjustable. The box was filled with the sample from constant height $(15 \mathrm{~cm})$, and then the adjustable plate was inclined gradually allowing the grains to fall freely and assume a natural slope, this was measured as angle of repose.

\section{Thousand-grain weight (M1000)}

One thousand randomly selected grains of test samples at various moisture levels were collected and weighed on electronic top pan 
balance (Contech, India) having a least count of $0.01 \mathrm{~g}$. This magnitude was termed as the thousand-grain weight specific to the grain. The procedure described in IS: 4333 (Part IV) -1968 was adopted. Average of ten replications have been considered and reported as a thousand grains weight of the sample.

\section{Bulk Density (BD)}

The bulk density of the grain is the ratio of its mass to bulk volume. Bulk density was measured using the IS:4333 (Part III)-1967 method, in which a $500 \mathrm{~mL}$ cylinder was filled with grains from a height of $15 \mathrm{~cm}$. The excess grains were removed by sweeping the surface of the cylinder and the grains were not compressed. Bulk density was then calculated as the ratio between the kernels weight and the volume of the cylinder (Gikuru Mwithiga, et al., 2005).

\section{True Density (TD)}

True density $\left(\rho_{t}\right)$ was determined using the toluene displacement method (Mohsenin, 1986; Singh et al., 1996). Toluene (40 ml) was filled in $100 \mathrm{ml}$ graduated measuring cylinder and $50 \mathrm{~g}$ of grains were poured in it. The amount of toluene displaced was recorded. The true density was estimated as the ratio of sample mass to the volume of displaced toluene.

\section{Density ratio}

It is the ratio of bulk density to true density. Calculated by the formula

\section{Density ratio $=\mathrm{BD} / \mathrm{TD}$}

\section{Porosity $(\epsilon)$}

It is the percentage of the volume of voids in the test sample at given moisture content and calculated as the ratio of the difference in the true and bulk density to true density value which is expressed in percentage with the following equation. The average of ten replications was considered as a percent porosity value of the sample.

$\epsilon=1-(B D / T D)$

\section{Static coefficient of friction $(\boldsymbol{\mu})$}

The coefficient of static friction of samples of sorghum grain was determined concerning four surface materials including plywood, glass, galvanized iron and mild steel to study the flowability of the samples through the hopper with reduced friction as reported by Shashikumar et al., (2018), and Obi et al., (2014). The coefficient of friction was calculated using the equation.

$\mu=\tan \theta$

where,

$\mu=$ coefficient of friction; and

$\theta=$ angle of inclination of the material surface.

\section{Terminal velocity}

The terminal velocity of sorghum grain was measured by using an air column Singh \& Goswami (1995), Sial et al., (2019). It is the velocity of air at which the grain is neither blown upward nor fallen downward; rather remains in the suspended state.

\section{Results and Discussion}

The results on the physical properties of sorghum grain (Variety: Pusa chari) such as linear dimensions and average diameters within the moisture range of 8.7 percent to 21.8 percent have been placed in Table 1 . 
Effect of moisture content on linear dimensions and average diameters

The linear dimensions i.e. length, width \& thickness of sorghum grain were found to increase significantly within the moisture content range from 4.54 to $4.80 \mathrm{~mm}, 3.55$ to $3.87 \mathrm{~mm}$, and 2.24 to $2.43 \mathrm{~mm}$ respectively which may be due to absorption of moisture by sorghum grain. The increase of length, width, and thickness were found linearly related to the corresponding increase in moisture content (Fig. 1). Similarly, the average diameters i.e., AMD, GMD, SMD, and EQD were observed to increase linearly with an increase in moisture content within the same range (Fig. 1). It was observed that the AMD, GMD, SMD, and EQD increased significantly from 3.38 to $3.53 \mathrm{~mm}, 3.20$ to $3.53 \mathrm{~mm}, 5.74$ to $6.30 \mathrm{~mm}$, and 4.11 to 4.51 $\mathrm{mm}$ respectively with the corresponding moisture content from $8.7 \%$ to $21.8 \%$ (Table 1). The observations of an increase in linear dimensions and average diameters of sorghum grain with regard to an increase in moisture content agree with the findings reported by Simonyan et al., (2005) and Kenghe et al.,(2015).

\section{Effect of moisture content on physical properties of Sorghum}

The physical properties i.e. aspect ratio, 1000 grain weight, sphericity, surface area, volume of sorghum grain have been placed in Table 2 which were found to increase significantly within the test moisture content from 73.78 to $80.54 \mathrm{~mm}, 20.67$ to $22.01 \mathrm{~g}, 0.705$ to 0.735 $\%, 32.27$ to $39.25 \mathrm{~mm}^{2}, 17.25$ to $23.13 \mathrm{~mm}^{3}$, 0.464 to 0.624 , respectively, which may be due to absorption of moisture by the sorghum grain. It was observed that physical properties were increased linearly with increase in moisture content from 8.7 to $21.8 \%$ (w.b.).
The increased value of physical properties within the corresponding moisture content were in agreement with the findings of Kenghe et al., (2015) for sorghum, Simonyan et al., (2005) and Gely et al., (2017) (Fig. 2).

The physical properties such as bulk density, true density and porosity of sorghum grain decreased with an increase in moisture content whereas density ratio increased within moisture content. It was observed that the bulk density, true density, and porosity decreased from 775.7 to $723.50 \mathrm{~kg} \mathrm{~m}^{-3}$, 1671.50 to $1161 \mathrm{~kg} \mathrm{~m}^{-3}, 0.536$ to $0.376 \%$, respectively with the corresponding moisture content range 8.7 to $21.8 \%$ (wb. The density ratio increased significantly within the test moisture content range from 0.464 to 0.624 . The decreased values of bulk density, true density, and porosity of sorghum grain coincides with the findings of Kenghe et al., (2015), Jambamma et al., (2011), Simonyan et al., (2005) (Fig. 3).

\section{Effect of moisture content on frictional and aerodynamic properties}

The result of the effect of moisture content on frictional and aero-dynamic properties of sorghum grain within the moisture content range of 8.7 to $21.8 \%$ (w.b) was presented in Table 3. The effect of moisture content on the angle of repose and terminal velocity was found to be statistically significant (Table 2). The lowest and highest value of the angle of repose was $39.84^{\circ}$ and $43.19^{\circ}$ at $8.7 \%$ and $21.8 \%$ moisture contents respectively. These findings are in agreement with Mitthiga and Mark (2006), Gely et al., (2017). The result showed that the terminal velocity increased linearly with an increase in test moisture content range from 7.06 to $7.99 \mathrm{~ms}^{-1}$. These results are in coincidence with the findings of Sial et al., (2019) (Fig. 4). 
Table.1 Effect of moisture content on the physical properties of Sorghum grain (Linear dimensions and Average diameters)

\begin{tabular}{|c|c|c|c|c|c|c|c|}
\hline \multirow{2}{*}{$\begin{array}{l}\text { Moisture } \\
\text { content }\end{array}$} & \multicolumn{3}{|c|}{ Linear Dimensions,mm } & \multicolumn{4}{|c|}{ Average Diameter,mm } \\
\hline & $\begin{array}{l}\text { Length } \\
\text { (L) }\end{array}$ & $\begin{array}{l}\text { Width } \\
\text { (W) }\end{array}$ & $\begin{array}{l}\text { Thickness } \\
\text { (T) }\end{array}$ & $\begin{array}{l}\text { Arithmetic } \\
\text { mean } \\
\text { diameter } \\
\text { (AMD) }\end{array}$ & $\begin{array}{l}\text { Geometric } \\
\text { mean } \\
\text { diameter } \\
(\mathrm{GMD})\end{array}$ & $\begin{array}{l}\text { Square } \\
\text { mean } \\
\text { diameter } \\
\text { (SMD) }\end{array}$ & $\begin{array}{l}\text { Equivalent } \\
\text { mean } \\
\text { diameter } \\
\text { (EQD) }\end{array}$ \\
\hline 8.7 & 4.54 & 3.55 & 2.24 & 3.38 & 3.20 & 5.74 & 4.11 \\
\hline 11.6 & 4.60 & 3.48 & 2.30 & 3.46 & 3.29 & 5.88 & 4.21 \\
\hline 14.8 & 4.67 & 3.65 & 2.34 & 3.55 & 3.38 & 6.05 & 4.33 \\
\hline 17.7 & 4.73 & 3.76 & 2.39 & 3.63 & 3.46 & 6.17 & 4.42 \\
\hline 21.8 & 4.80 & 3.87 & 2.43 & 3.70 & 3.53 & 6.30 & 4.51 \\
\hline $\mathrm{CD}_{0.05}$ & 0.02 & 0.02 & 0.02 & 0.01 & 0.01 & 0.02 & 0.01 \\
\hline $\operatorname{SE}(m) \pm$ & 0.02 & 0.01 & 0.01 & 0.01 & 0.01 & 0.01 & 0.01 \\
\hline
\end{tabular}

Table.2 Physical properties of sorghum grain

\begin{tabular}{|l|c|c|c|c|c|c|c|c|c|}
\hline $\begin{array}{l}\text { Moisture } \\
\text { content, }\end{array}$ & $\begin{array}{c}\text { Aspect } \\
\text { ratio }\end{array}$ & Sphericity & $\begin{array}{c}\mathbf{1 0 0 0} \\
\text { grain } \\
\text { weight }\end{array}$ & $\begin{array}{c}\text { Surfac } \\
\text { e area }\end{array}$ & Volume & $\begin{array}{c}\text { Bulk } \\
\text { density }\end{array}$ & $\begin{array}{c}\text { True } \\
\text { density }\end{array}$ & $\begin{array}{c}\text { Densit } \\
\text { y ratio }\end{array}$ & Porosity \\
\hline $\mathbf{8 . 7}$ & 73.78 & 0.705 & 20.67 & 32.27 & 17.25 & 775.75 & 1671.50 & 0.464 & 0.536 \\
\hline $\mathbf{1 1 . 6}$ & 75.65 & 0.718 & 21.03 & 33.99 & 18.64 & 766.50 & 1565.75 & 0.490 & 0.510 \\
\hline $\mathbf{1 4 . 8}$ & 78.07 & 0.725 & 21.52 & 35.95 & 20.28 & 758.75 & 1362.75 & 0.558 & 0.442 \\
\hline $\mathbf{1 7 . 7}$ & 79.45 & 0.730 & 21.84 & 37.68 & 21.76 & 744.00 & 1272.75 & 0.586 & 0.414 \\
\hline $\mathbf{2 1 . 8}$ & 80.54 & 0.735 & 22.01 & 39.25 & 23.13 & 723.50 & 1161.00 & 0.624 & 0.376 \\
\hline $\mathbf{C D}_{\mathbf{0 . 0 5}}$ & 0.58 & 0.006 & 0.15 & 0.20 & 0.16 & 6.40 & 45.67 & 0.022 & 0.022 \\
\hline $\mathbf{S E}(\mathbf{m}) \pm$ & 0.19 & 0.002 & 0.05 & 0.06 & .05 & 2.05 & 14.66 & 0.007 & 0.007 \\
\hline
\end{tabular}

Table.3 Frictional and Aerodynamic properties of Sorghum

\begin{tabular}{|c|c|c|c|c|c|c|}
\hline \multirow{2}{*}{$\begin{array}{l}\text { Moisture } \\
\text { content } \\
(\%)\end{array}$} & \multirow{2}{*}{$\begin{array}{l}\text { Angle of } \\
\text { Repose } \\
\left({ }^{0}\right)\end{array}$} & \multicolumn{4}{|c|}{ Coefficient of friction at different surfaces } & \multirow{2}{*}{$\begin{array}{l}\text { Terminal } \\
\text { velocity }^{-1}\left(\mathrm{msec}^{-1}\right)\end{array}$} \\
\hline & & Glass & $\begin{array}{l}\text { Mild steel } \\
\text { sheet }\end{array}$ & GI sheet & Plywood & \\
\hline 8.7 & 39.84 & 0.25 & 0.26 & 0.27 & 0.30 & 7.06 \\
\hline 11.6 & 40.80 & 0.26 & 0.28 & 0.28 & 0.32 & 7.18 \\
\hline 14.8 & 41.84 & 0.28 & 0.31 & 0.31 & 0.41 & 7.46 \\
\hline 17.7 & 42.41 & 0.30 & 0.34 & 0.35 & 0.42 & 7.74 \\
\hline 21.8 & 43.19 & 0.31 & 0.43 & 0.42 & 0.45 & 7.99 \\
\hline $\mathrm{CD}_{0.05}$ & 0.51 & 0.01 & 0.01 & 0.01 & 0.01 & 0.07 \\
\hline $\mathrm{SE}(\mathrm{m}) \pm$ & 0.16 & 0.01 & 0.01 & 0.01 & 0.01 & 0.02 \\
\hline
\end{tabular}


Fig.1 Effect of moisture content on linear dimensions and average diameters of sorghum grain

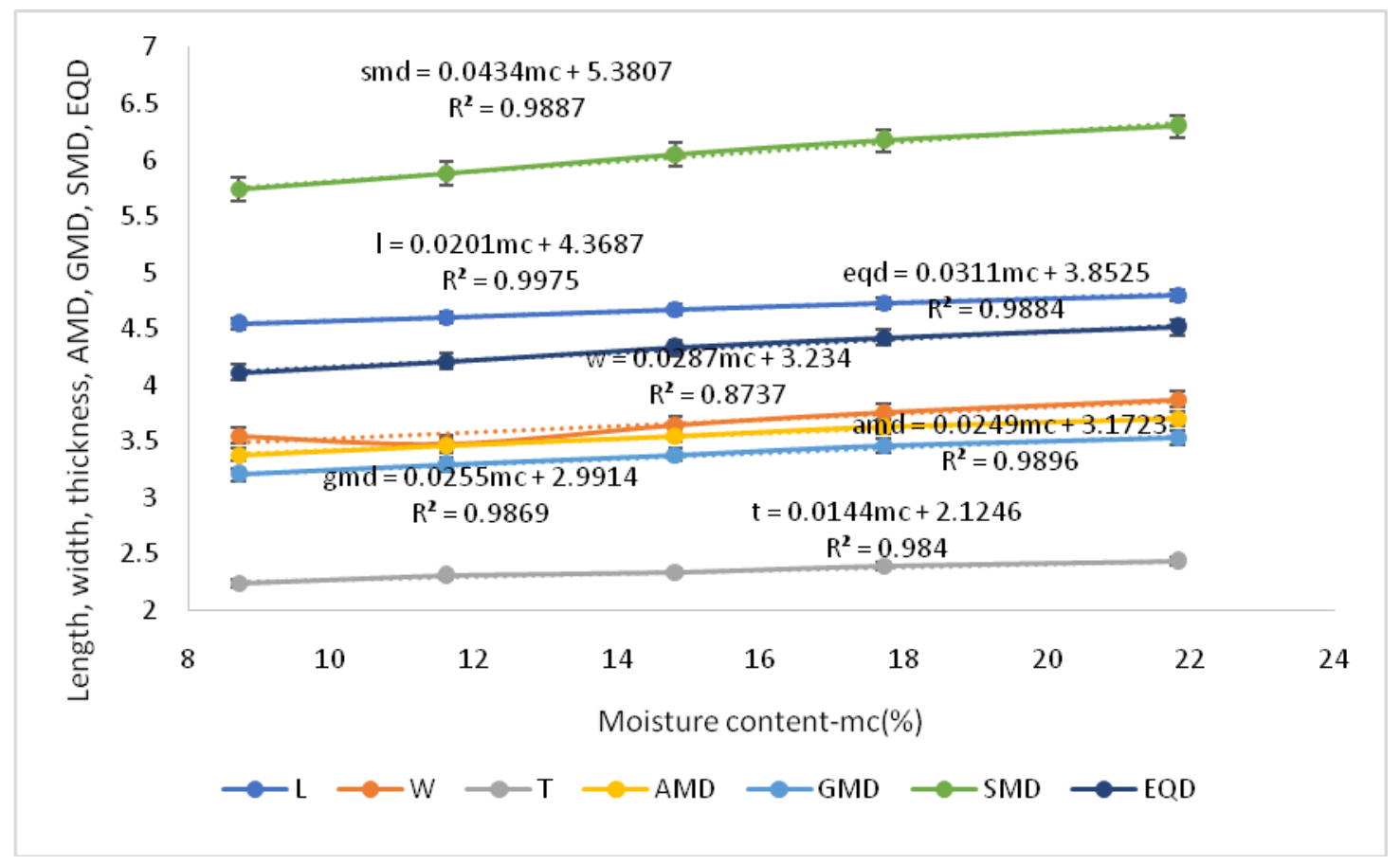

Fig.2 Effect of moisture content on aspect ratio, 1000 grain weight, surface area, volume, and sphericity of sorghum grain

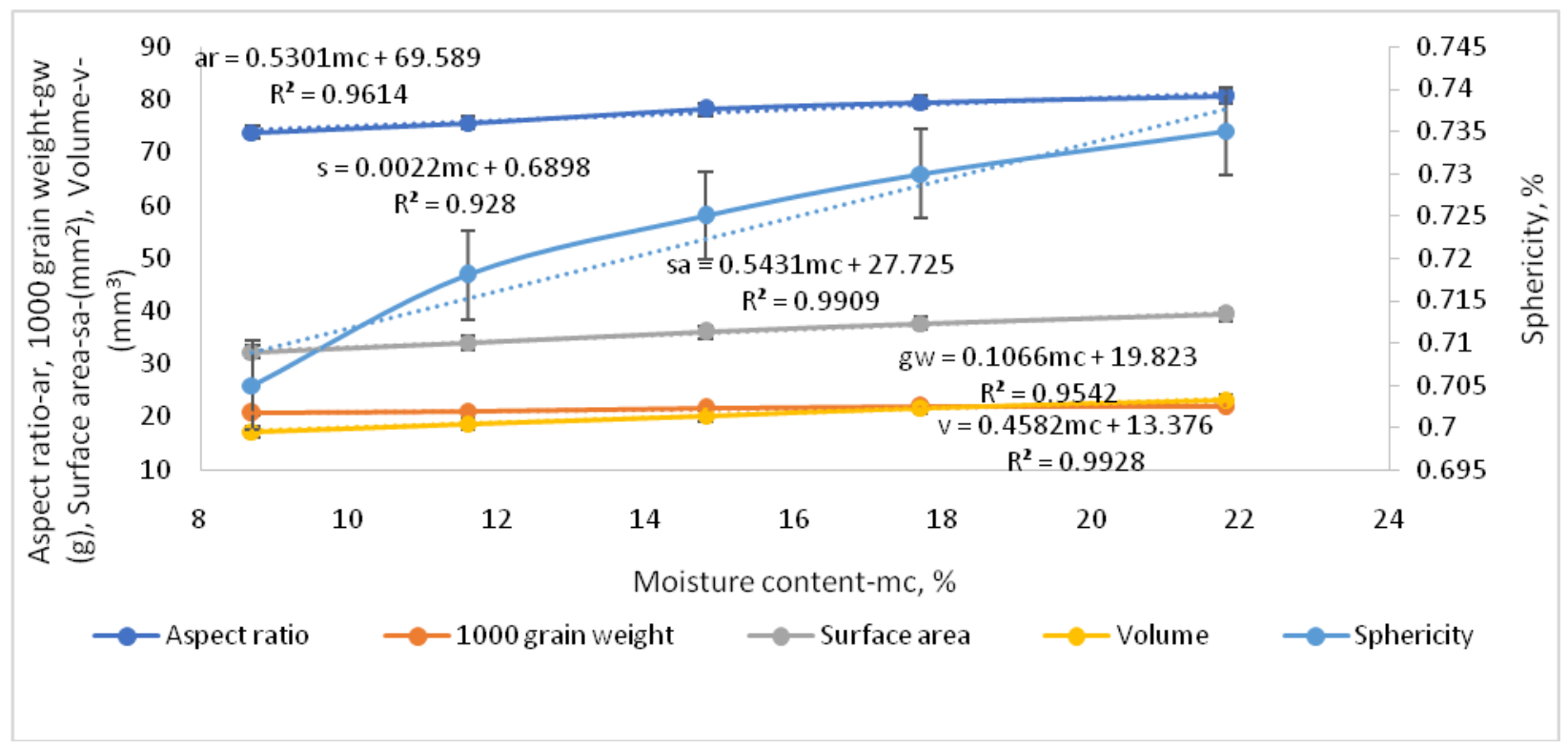


Fig.3 Effect of moisture content on bulk density, true density, density ratio and porosity of sorghum grain

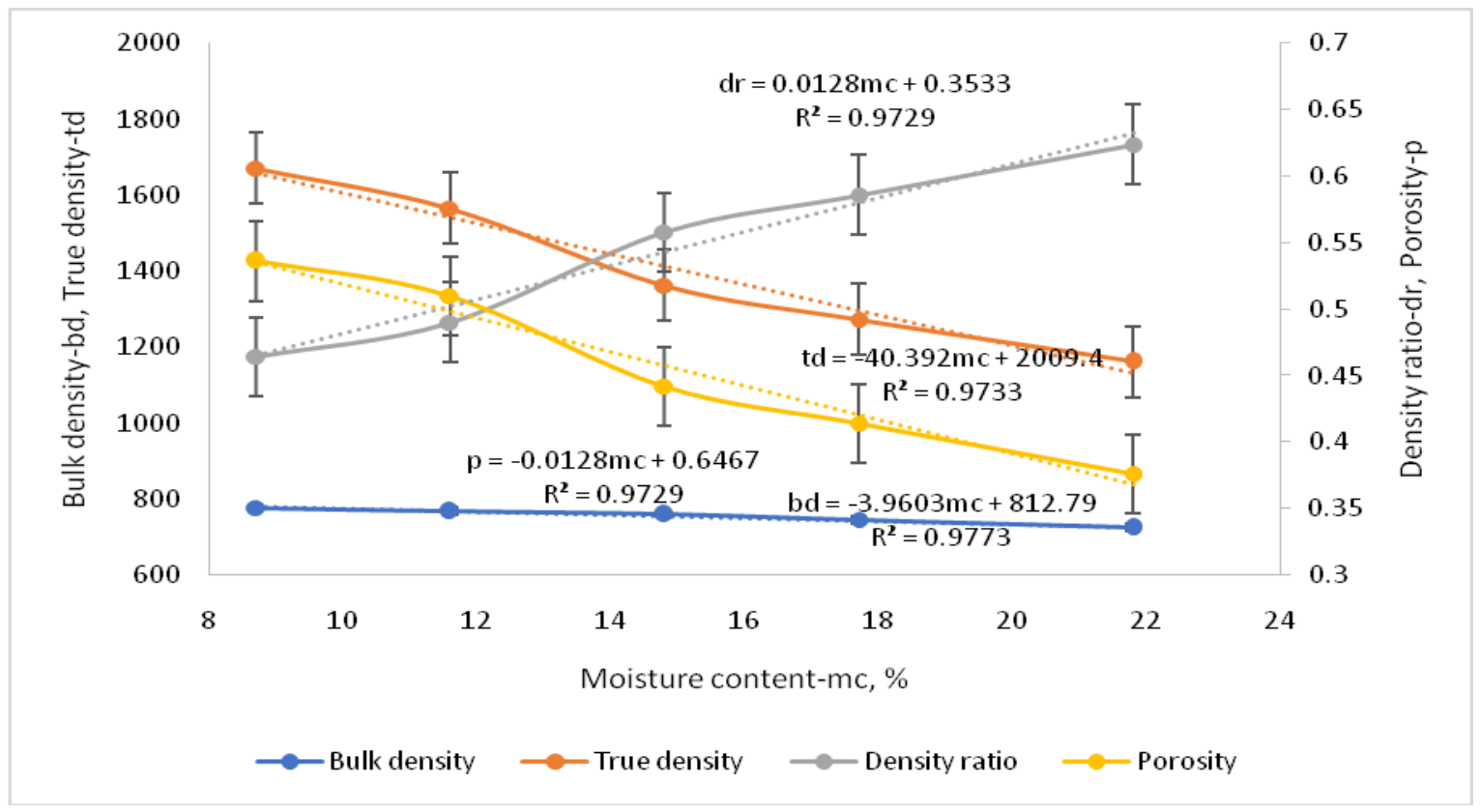

Fig.4 Effect of moisture content on the coefficient of friction, terminal velocity and angle of repose of sorghum grain

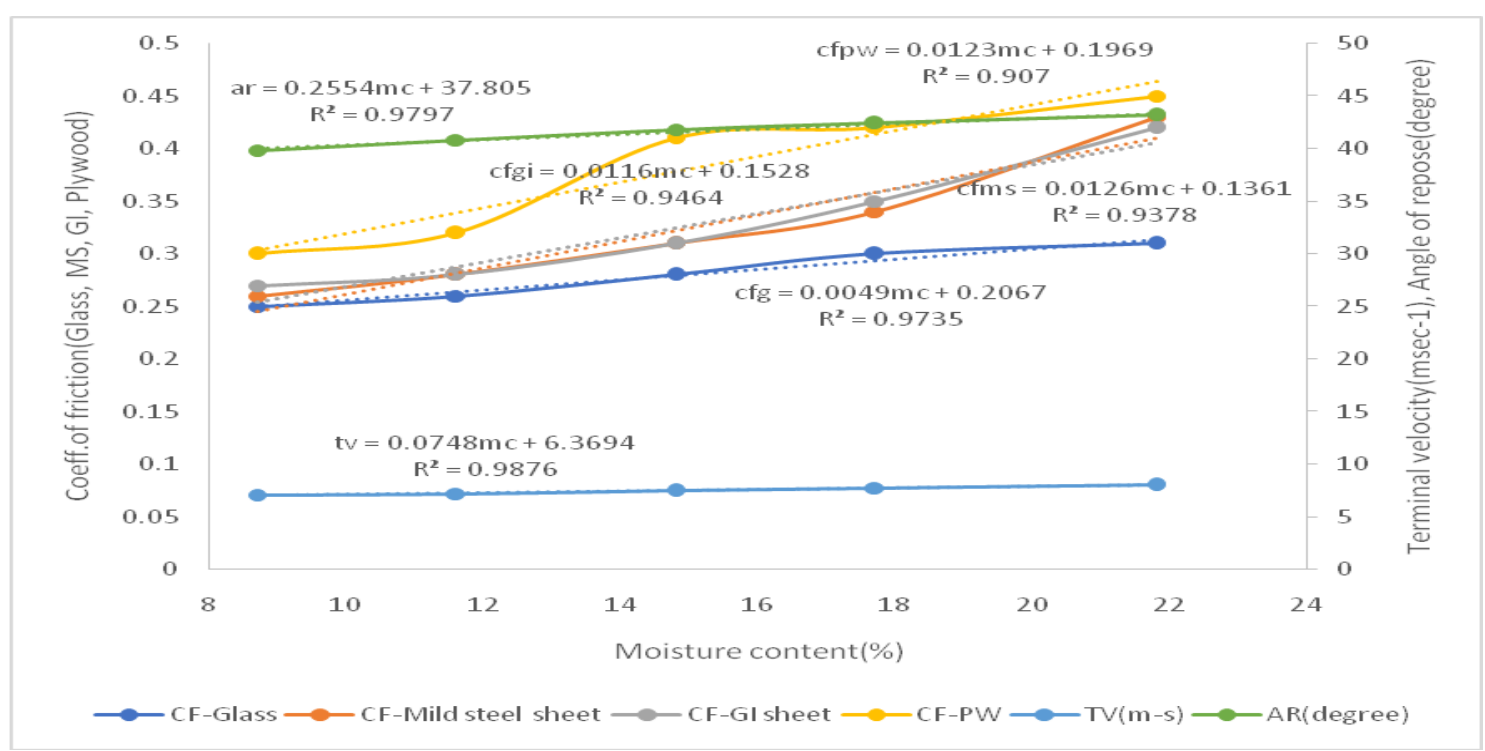

The coefficient of friction of sorghum grain was determined concerning four different surfaces within the test moisture range from 8.7 to $21.8 \%$ (wb). It was observed that the coefficient of friction for all the contact surfaces was increased linearly with an increase in moisture content. The data revealed that the lowest value of glass, mild steel sheet, GI sheet and plywood were found to be $0.25,0.26,0.27$ and 0.30 at $8.7 \%$ (wb) moisture content and the highest value of $0.31,0.43,0.42$ and 0.45 respectively at 
$21.8 \%$ (wb) moisture content. The coefficient of friction for glass was lowest as compared to other surfaces whereas the value of the coefficient of friction for plywood was highest as compared to other surfaces. These findings are in agreement with the earlier findings of Kenghe et al., (2015), Gely et al., (2017) and Jambamma et al., (2011).

In conclusion, the present study provides a comprehensive basic information about the engineering, frictional and aerodynamic properties of sorghum grain for designing small scale post-harvest machinery especially a sorghum thresher for small and marginal farmers which include the coefficient of friction for designing of sieve slope, angle of repose for designing of hopper and feeding chute, terminal velocity for designing of blower and aspirator and grain size (GMD, SMD, AMD \& EQD) for designing of sieve openings, size of holes and concave clearance.

\section{References}

Abalone, R., A. Cassinera, A. Gastón, and M. A. Lara. 2004. Some physical properties of amaranth seeds. Biosystems Engineering, 89(1): 109117.

American Association for Clinical Chemistry's (AACC). 1995. Approved methods of the AACC (9th ed). Method 08-01, revised October 1981; Method 44-15A, revised October 1994; Method 46-18, revised October 1994; Method 76-13, approved November 1995. The Association: St. Paul,MN.

Anonymous. ICRISAT. 1999. The world sorghum and millet economies: facts, trends and outlook. ICRISAT, Patancheru, India, Pp: 38-75.

Anonymous.

Sorghum http://www.icrisat.org/whatwedo/crop s/sorghum/sorghum.htm

Anonymous. Sorghumarea India https://www.indexmundi.com/agricult ure/?country=in\&commodity=sorghu $\mathrm{m} \&$ graph$=$ production

Asoegwu S, Ohanyere S, Kanu O, and Iwueke C. (2006) Physical properties of African oil bean seed. Agril. Engg., Int.: the CIGR (e-J.). Manuscript, FP 05 006. VIII. Biosystems Engineering, 82(1), 73-78.

Brooker, D. B., F. Bakker-Arkema, and C. W. Hall. 1992. Drying and Storage of Grains and Oilseeds. New York: Van Nostrand Reinold.

Chang, C. S. (1988) Measuring density and porosity of seed kernels using a gas pycnometer. Cereal Chemistry. 65 (1): $13-15$.

Coskun, M.B., I. Yalçin and C. Özarslan, (2005) Physical properties of sweet corn seed (Zea mays saccharata Sturt.). J. Food Engg., 74(4): 523-528.

Gely, M. C., and A. M. Pagano. 2017. Effect of moisture content on engineering properties of sorghum grains. Agricultural Engineering International: CIGR Journal, 19(2): 200-209

Harvesting of sorghumhttp://agropedia.iitk.ac.in/content/harv esting-sorghum

Hurburgh, Jr. C. R. 1995. An economic model of corn cleaning. Applied Engg., In Agri. 11 (4) 539-547.

Jambamma, Imaya Kumari, and A. Kailappan. 2011. "Study of physicochemical properties of food grain sorghum and product ready-tocook mix food from sorghum." International Journal of Recent Scientific Research 1.3: 96-99.

Kachru, R. P., R. K. Gupta, and A. Alam. 1994. Physico-chemical constituents and engineering properties of food crops. 1st ed. Jodhpur, India: 
Scientific Publishers.

Kenghe. R. N., M. S. Jadhav, C. A. and Nimbalkar. 2015. Physical properties of sorghum (Sorghum bicolor) grains as a function of moisture content. International Journal of Engineering Sciences \& Research Technology, 4(10), 496-504.

Maduako J.N; Faborode M.O (1990). Some physical properties of cocoa pods in relation to primary processing. Ife Journal of Technology 2,1-7.8

Mohsenin N.N. (1970). Physical properties of plant and Animal material. Gordon and Breach Science Publisher, New York. Pp.742.

Mohsenin N.N., (1980) Structure, physical characteristics and mechanical properties of plant and animal materials. Gordon and Breach Press, New York.

Mohsenin, N. N. (1986). Physical properties of plant and animal materials. New York: Gordon and Breach Science Publishers.

Mwithiga, G., and M. M. Sifuna. 2006. Effect of moisture content on the physical properties of three varieties of sorghum seeds. Journal of Food Engineering, 75(4): 480-486.

Nelson, S O. (1980) Moisture- dependent kernel and bulk density relationships for wheat and corn. Transactions of the American Society of Agril. Engineers 23(1):139- 143.

Nelson, S. O. and T. S. You. (1989) Microwave dielectric properties of corn and wheat kernels and soybeans at microwave frequencies. Transactions of the American Society of Agril. Engineers 32(1):242-249.

Obi, O. F., Anyadike, C. C. and Onyeke, C, O. 2014.Moisture-dependent physical properties of pigeon pea grown in Nigeria. Journal of World Applied Sciences, 31 (8): 1396-1405.
Oke, B. O. 1984. Physical and mechanical properties of sorghum (sorghum bicolor) stalk harvested at various intervals after grain maturity. Agricultural Wastes, 11(1): 31-45.

OPSTAT, Free online Agriculture Data Analysis Tool, https://sites.google.com/site/freebiotoo ls/online-biotools/agri-biotools/opstat

Sial, S.K., S.K. Swain, D. Behera, P.M Mohapatra, A.K Mohapatra and A.K Dash (2019). Moisture related engineering properties of different OUAT released varieties of ragi. Green farming Vol. 10(3):341:345.

Shashikumar, G., Meera Pandey, and A. Carolin Rathinakumari. 201. "Physical and engineering properties of sorghum grain towards development of spawn spreading machine for oyster mushroom (Pleurotus florida) cultivation." The Andhra Agric. J 65 (spl): 175-178, 2018.

Simonyan, K. J. (2005) The effects of moisture contents on some engineering properties of Bambara groundnut. Samaru J. Agril. Res.21:73-85.

Singh K, Mishra H, Saha S (2010). Moisturedependent properties of barnyard millet grain and kernel. Journal of Food Engineering 96(4), 598-606.

Singh, K. K., and Goswami, T. K. 1996. Physical properties of cumin seed. Journal of Agricultural Engineering Research. 64(2):93-98.

Sologubik, C., L. Campañone, A. M. Pagano, and M. C. Gely. 2013. Effect of moisture content on some physical properties of barley. Industrial Crops and Products, 43(5): 762-767.

Taylor, J., and P. Shewry. 2006. "Preface to sorghum and millet reviews," Journal of Cereal Science, vol. 44, no. 3, p. 223.

Tettamanti, A., A. M. Pagano, and M. C. 
Gely. 2015. Efecto del contenido de humedad Sobrepropiedadesfísicas de una variedad Argentina de sorgo granífero. In Proc. XV Congreso Argentino de Ciencia y Tecnología de Alimentos.

Vaughan, C. E., B. R. Gregg. and J. C. Delouche.1980. Seed Processing and Handling. Seed Tech. Lab. handbook
1. Mississipi State University. Mississipi America.

Vilche, C., M. Gely, and E. Santalla. 2003. Physical properties of quinoa seeds. Biosystems Engineering, 86(1): 59-65.

Wilhelm, L. R., D. A. Suter, and G .H. Brusewitz. 2004. Physical properties of food materials. (Chapter 2) in Food and Process Engg. Tech. 23-52.

\section{How to cite this article:}

Sabar, S. S., S. K. Swain, D. Behera, K. Rayaguru, A. K. Mohapatra and Dash, A. K. 2020. Moisture Dependent Physical and Engineering Properties of Sorghum Grains. Int.J.Curr.Microbiol.App.Sci. 9(08): 2365-2375. doi: https://doi.org/10.20546/ijcmas.2020.908.271 